\title{
Alfabetização e reabilitação dos distúrbios de leitura/escrita por metodologia fono-vísuo-articulatória****
}

\author{
Alphabetization and rehabilitation of reading/writing disorders \\ through a phonetic-visual-articulatory method
}

\author{
Renata Savastano Ribeiro Jardini* \\ Patrícia Thimóteo de Souza**
}

*Fonoaudióloga. Doutoranda em Pediatria pela Universidade Estadual de Campinas. Pesquisadora do Centro de Pesquisas e Tratamento das Deformidades Buco-Faciais de Araraquara. Endereço para correspondência: Av. Joaquim de Souza Pinheiro, 58 - SP - CEP: 14.802.020 (rsjardini@aol.com).

**Pedagoga. Psicopedagoga pela Universidade Central Paulista - São Carlos.

***Trabalho Realizado no Espaço Pedagógico Fonoaudiológico, Araraquara - SP. A metodologia fonovísuo-articulatória foi denominada, pelas crianças, de Método das Boquinhas, termo mantido no presente artigo.

Artigo de Pesquisa

Artigo Submetido a Avaliação por Pares

Conflito de Interesse: não

Recebido em 12.02.2004

Revisado em 31.03.2004; 12.07.2004; 20.06.2005; 12.07.2005; 17.09.2005; 03.02.2006; 17.03.2006. Aceito para Publicação em 17.03.2006

\begin{abstract}
Background: alphabetization and rehabilitation of reading/writing disorders through a phonetic-visualarticulatory method (Método das Boquinhas - Jardini, 1997). This methodology combines neuropsychological inputs, such as sounds/phonemes, letters/graphemes to the visual representation of mouth position/articulemes. Aim: to alphabetize and/or rehabilitate children who presented reading/writing disorders, of varied etiologies, with consistent short-term results, in a combined intervention with a speech-language pathologists and a psycho-pedagogue. Method: participants of this study were 30 children, with the diagnoses of dyslexia, ADHA, mild cognitive retardation, infant psychoses and borderline behavior, some of which presented comorbidities. Children ranged between 7 and 10 years of age, all presenting at least a six-month delay in regular schooling. The children along with their parents and teachers took part in the research. Parents and teachers assessed the children through a multiple choice questionnaire at the beginning of treatment (T0), three (T1) and six months after intervention (T2), according to parameters of reading, reading comprehension, spelling, blackboard copying, attention, concentration and confidence for learning. The questionnaire qualified children as incapable, intermediate and capable for learning in each of the assessed parameter. The adopted therapeutic approach was the application of a phonetic-visual-articulatory method, with two weekly sessions with a speech-language pathologist and a psycho-pedagogue. Besides the therapeutic interventions, children continued to attend regular school. Results: an expressive development was observed for all of the assessed parameters, according to parents and teachers. After the first 3 months of intervention, the performance of the children was classified at an intermediate level of learning and after 6 months they were considered as being capable for learning in each of the assessed parameters. These results not only favored a better performance at school, but also raised the children's self-esteem in terms of learning. Conclusion: after 6 months of intervention with the phonetic-visual-articulatory methodology children were able to continue with their learning process in a regular school, following the performance of the other members of class.
\end{abstract}

Key Words: Reading and Writing Disorders; Teaching; Learning.

\section{Resumo}

Tema: alfabetização e reabilitação dos distúrbios da leitura e escrita por metodologia fono-vísuo-articulatória (Método das Boquinhas - JARDINI, 1997). Esta metodologia de aprendizagem alia inputs neuropsicológicos, como os sons/fonemas, às letras/grafemas, às boquinhas/articulemas. Objetivo: alfabetizar e/ou reabilitar crianças que apresentavam distúrbios na leitura e escrita, de etiologia variada, com resultados consistentes a curto prazo, num trabalho de parceria entre fonoaudiólogo e psicopedagogo. Método: participaram deste estudo 30 crianças, com diagnósticos de dislexia, TDHA, atraso cognitivo leve, limítrofes e psicoses infantis, havendo co-morbidades entre os casos. As crianças variavam entre 7 a 10 anos de idade, todas com atrasos de pelo menos seis meses na escolaridade regular. Participaram da pesquisa as crianças, seus pais e professores, que avaliaram-nas por meio do mesmo questionário, no início do tratamento (T0), após 3 meses (T1) e após 6 meses de intervenção (T2), segundo a leitura, interpretação de textos, ditado, cópia da lousa, atenção, concentração e segurança para aprendizagem. Foram aplicados questionários de múltipla escolha, sendo qualificadas em incapaz, intermediária e capaz para a aprendizagem do quesito avaliado. A abordagem terapêutica adotada foi a aplicação do método fono-vísuo-articulatório (Método das Boquinhas - Jardini, 1997), com duas sessões semanais realizadas pela fonoaudióloga e pela psicopegagoga. Além da intervenção as crianças continuaram sua escolaridade na rede regular de ensino que freqüentavam. Resultados: houve expressiva evolução em todos os itens avaliados, analisados pelos pais e pelos professores. Após os 3 primeiros meses de intervenção as crianças passaram para nível intermediário de aprendizagem e após 6 meses apresentaram-se capazes em cada item avaliado. Estes resultados não só propiciaram melhor rendimento escolar, como beneficiaram-nas em relação à auto-estima para aprendizagem, podendo melhor enfrentar suas diferenças. Conclusão: com a metodologia fono-vísuo-articulatória, após 6 meses as crianças estavam aptas à dar continuidade no processo regular de ensino, acompanhando os demais alunos de sua classe.

Palavras-Chave: Ruído; Audiometria de Frequiências Ultra-Altas; Audição; Perda Auditiva Induzida pelo Ruído.

JARDINI, R. S. R.; SOUZA, P. T. Alphabetization and rehabilitation of reading/writing disorders through a phonetic-visual-articulatory method (original title: Alfabetização e reabilitação dos distúrbios de leitura/escrita por metodologia fono-vísuo-articulatória). Pró-Fono Revista de Atualização Científica, Barueri (SP), v. 18, n. 1, p. 69-78, jan.-abr. 2006. 


\section{Introduction}

During our course in speech and hearing clinics we have beheld some schools failed with their children regards reading and writing disorders, whom by feeling desencouraged let their fathers and teachers misbelieve their real capacities. Speech and hearing is a relative new science, but with a large background, since it deals with language and communication, including reading and writing.

One hand, reading and writing is a toll which offers to its users a major power and may lead the human being to happiness, success and prosperousness. On the other hand, it may cause discrimination, impairment and shame, in such cases when we confront the reality of numerous functional-literate children and of inside-schoolexclude children, who attend advanced school levels, but apart from their names, are incapable to spontaneous reading and writing Nowadays we may face more inside than outside exclusion. Every one may attend the educational system, with their own history and accidental course and along with few chances to get somewhere, in reason to their own educators, who start from no point that leads to significant place (Fernandez, 2001).

Psychopedagogy science, by it turns, attempts to find its identity, based on the necessity of absorbing and comprehending the teaching/ learning process, in order to prevent and rehabilitate educational disorders and to give the human being, as the history author, more credibility.

And from this circumvention, it comes the necessity of "socialising" speech and hearing science and leagues it to psychopedagogy, basing on both sciences complete justify and transform each other, hence this acquaintanceship may offer new manners of teaching and learning the literacy process (Jardini, $2004 \mathrm{a}, \mathrm{b}$ ). The conception of "Método das Boquinhas" (little-mouths method) (Jardini e Vergara, 1997; Jardini, 2003a; b), conjoined with pedagogue and psychopedagogue corroborates our intention that by the integrated work of the both areas we may get a successful intervention in a short time, which will emerge children's/client's credibility and self-assurance.

According to Collares and Moyses (1992), the use of the expression "learning disorder" has widespread among teachers, in defiance of most educators not always clarifies the meaning of this expressions nor the criteria involved to its use on educational setting. The authors explain the use of "learning disorders" in educational setting as either the reflex of the pathological process of learning or the biologization of the social issues. Tannús and Fellipe (2002) point that teacher's view is back to children's disorder and their cultural background, by analysing 322 children, out of 1393 , who present some educational difficulty. The same suggest Ciasca and Rossini (2000), who affirms that it is growing larger the number of (even) preschool and primary school children complaing of failing on educational development refering to neurology sectio.

It is requirement the educator undoes his prejudice with regards to the "problematicstudent", and sets out him as a person with learning-opportunity, as some one who provides means to contribute and promote children's and parents' thinking evolution. As affirms Franchi (1992) it is assumed that writing language connects all the significant constitutive and constituted process by and to the subjects, granting them the toll to socialise, to adapt and to organise themselves. Thus, habilitate and rehabilitate the unlearned subject is the better choice to restitute his self domain and significance as a learning and thoughtful human being.

Among the usual definition, on one hand, the term "learning-difficulty" is related to psychopedagogue and/or socio-cultural problems. It means that the issue is not only centred on the student, it also includes a more prevailing view, including the delays on educational development by either a lack of interest, a methodological inadequacy or a change on school demandatory pattern. On the other hand, the terms "disorder" and "deficit" are more associated to the student intrinsic problems, suggesting the presence of neurological issues, and are often used in clinical or rehabilitation setting.

In conclusion, when we encounter a child that has presenting some difficulties to learning, it is important to acutely examine the stimulation offered to this child pertaining to quantity, qualitative, accessibility and motivation, exclusivity and unconditionally, which may contribute to the diagnosis and the therapeutic strategy.

The speech and hearing therapist is adhered to be the right professional to deal with learning disorders, who may act toghether with others professional, such as the psychopedagogue as previously mention. Specifically regarding learning difficulties, which do not involve language acquisition and development disorders, the child 
may be refered to the psychopedagogue (Jardini, $2004 \mathrm{a}, \mathrm{b})$ or may be attended in the classroom (Tannús and Felippe,2002; Fraga, 2001). This fact may acquaint us that the school may not be prepared to deal with children who do not fit the "normal" learning-pattern. It is the responsible of the speech and hearing professional to abet in capacitating educators to successfully promote reading and writing acquisition, returning the educator's functions and the education mission. Based on the assertive above, the little-mouths method (Método das Boquinhas) was developed.

The aim of this study was to support the intervention program designed by the Método das boquinhas (little mouth method), developed in conjunction with speech and hearing and psychopedagogy science, by using the scientific research, in order to alphabetise/literate and rehabilitate reading and writing disorders, presented in children with different aetiologies.

Theoretical bases to Método das Boquinhas (Little - mouths Method)

Multisensorial phono-visuo-articulatory bases supports the method conception and development, toward providing a better and more efficient educational performance, since children is simultaneously submitted to several neurossensorial inputs, and leaning major cerebral areas to be stimulated.

We have chosen the speech and its sounds as the start point to letters (graphemes) acquisition, as directed by the phonic method, directly dealing with phonological analysis ability (Dominguez, 1994; Cielo, 2002) and phonological awareness (Capovilla and Capovilla, 2002; Santos and Navas, 2002), in addtion to the articulatory awareness. It means the articulatory point of each letter is isolated produced (articulemes, or "little- mouths"), and based on the phonological-articulatory principles -FAR-, which ascribes the phoneticalphonological unit, par excellence, the articulatory gesture (Browman and Goldstein, 1986; Albano, 2001).

As pointed by Souza (2005) phonological awareness is the ability to explicit reflect about the word sound structure, manipulating its components (Carvalho e Alvarez, 2000), meanwhile phonemic awareness is the ability to reflect about the phonemes. Phonological awareness independent on the word meaning, as write Stackhouse et al. (2002). Conversely, syntactic and semantic and pragmatic ability, meaning, linguistic awareness or metalinguistic, and metacognitive abilities, are related to Piaget's concrete-operatory period, developed during the school years, outgrown from specific activities (Yavas and Haase, 1988).

In a recent research with scholars from 1 st degree of fundamental school, Souza (2005), corroborating Hulme et al (2002), implies phonological awareness as the best predictor for reading and writing acquisition, and may be practised during alphabetisation, since it not spontaneously acquired by children. Vieira et al (2004) believe that the expected age to complete phonological system learning is about five years old and may be extended to maximum of six. Lazarotto and Cielo (2002); Cielo (2003); Cavalcante and Mendes (2003) and Souza (2005) observe and affirm that supraphonemic ability, such as syllable detection, preceded and succeed phonemic abilities.

Cielo (2002) states in her studies that phonemic detection does not include the complete phonemic awareness, inasmuch as little children, even when do not master the alphabetic code, present mild features of phonological awareness. Roth and Baden (2001) affirm that around three and four years old, children seems to master rhymes and alliterations, which are required to reading and writing acquisition. 
As declares Massi and Berberiam (2005) it is assumed that reading and writing are not the same as decoding and coding groups of graphemes. Decoding confines the mechanical act of naming and identifying letters and grouping them into words and sentences, meanwhile comprehension represents a reflection act in which objects, world and people are recognised and made. This statement illustrates the little-mouths method propose, which does no disqualify the comprehension and the reflection about writing language, but supports and assures the metalinguistic occurrence. In other words, it promotes the coding and decoding, which is believed to be the inherent and anterior process to the significant use of reading and writing and not advocate language fragment or disconnection from its ideological content, corroborating Massi and berberiuam (2005).

For reading it is primary to decode and to extract the meaning, however, firstly it is necessary to learn the correspondence between the speech sounds and its graphemes (Andreazza-Balestrin and Cielo, 2003), considering that the statement are heard by a unit (Cielo, 1998). In order to children realise the relation between grapheme and phoneme, in alphabetical code, it is necessary mastering the phonological awareness ability (Cielo, 1998; Zorzi, 2000).

\section{Method}

This research was developed at Espaço Pedagógico Fonoaudiológico, a private institution for learning disorders, located in the countryside of the state of São Paulo, and supported by teachers from private and public schools, and by children and parents who participated on this research. The research project was accepted and approved by the pedagogical co-ordinators and submitted and approved by the Ethic Committee of the Universidade Estadual de Campinas/ Unicamp, protocol 360/2004. Both the school coordinator and parents signed the term of free consent, as resolution 196/96 by Comissão Nacional de Ética em Pesquisa (CONEP Ethic Committee) (Brazil, 1996).

Thirty children from 7 to 10 years old, 18 male and 12 female, participated on this study. Children were classified according to their reading and writing acquisition level and were attending preschool and 1st e 2nd degree of primary school. In addition, children's parent and teachers fill the questionnaires about children's performance.

All children selected to this study presented writing and reading acquisition and/or development delay.

Criteria for inclusion included more than 5 months difficulties to follow the educational content and school failed, in addition to a evaluation, applied by both speech therapist and psychopedagogue, classifying the children with a educational performance under the expected for their age.

Children presented different aetiology for reading and writing disorders. Ten children presented mild or borderline mental disorder, 14 dyslexia, 8 deficit of attention deficit hyperactivity disorder (TDHA), 3 psychoses. In several instances, children showed co-morbidity among the cases. A disciplinary team diagnosed (speech and hearing therapist, psychopedagogue, neurologist, psychiatric and familiar therapist,) children according to their specificity.

Children were individually evaluated according to their level of reading and writing acquisition and to their language functional system, provided by speech and therapist and pedagogue. There were equally distributed in three pre intervention groups. Level I: pre syllabically or initial syllabic, attending pre-school and comprising 6 failed children with no vowel domain; level II, final syllabic and syllabic-alphabetical stage, with children present a rudimental reading level; level III, alphabetical and literate children with severe and alphabetical with severe misspelling and text miscomprehension. Children's distribution was according to their performance, independent on their age and diagnosis, in order to provide a better intervention program.

The intervention program followed "Little mouth method" Método das Boquinhas and included 60 minute twice a week session with the speech pathologist and the pedagogue. Teachers continued with their regular classes, keeping the educational curricula. Once a week teachers get together to discuss and plan the activities. Once a month the parents and the school members were invited to participate to the orientation program, toward participating the process.

The evaluation method for each study phase (T0, T1, T2), included parents (annex 1) and teachers 
TABLE 1. Teachers' answers in $\mathrm{T} 0, \mathrm{n}=30$ children, $\mathrm{p}<0,01, ?=0,05$.

\begin{tabular}{c|c|c|c}
\hline Perguntas & Incapaz & Intermedifrio & Capaz \\
\hline 1 & 28 & 1 & 1 \\
2 & 25 & 5 & 0 \\
3 & 26 & 4 & 0 \\
4 & 27 & 3 & 0 \\
5 & 26 & 4 & 0 \\
6 & 24 & 6 & 0 \\
7 & 28 & 2 & 0 \\
\hline
\end{tabular}

TABLE 2. Teachers' answers in $\mathrm{T} 1, \mathrm{n}=30$ children, $\mathrm{p}<0,01, ?=0,05$.

\begin{tabular}{c|c|c|c}
\hline Perguntas & Incapaz & Intermedi/Fio & Capaz \\
\hline 1 & 9 & 19 & 2 \\
2 & 13 & 17 & 0 \\
3 & 10 & 19 & 1 \\
4 & 12 & 17 & 1 \\
5 & 14 & 16 & 0 \\
6 & 10 & 18 & 2 \\
7 & 13 & 17 & 0 \\
\hline
\end{tabular}

TABLE 3. Teachers' answers in $\mathrm{T} 2, \mathrm{n}=30$ children, $\mathrm{p}<0,01, ?=0,05$.

\begin{tabular}{c|c|c|c}
\hline Perguntas & Incapaz & Intermedi/kio & Capaz \\
\hline 1 & 0 & 21 & 9 \\
2 & 0 & 19 & 11 \\
3 & 1 & 22 & 7 \\
4 & 1 & 23 & 6 \\
5 & 4 & 22 & 4 \\
6 & 1 & 21 & 8 \\
7 & 2 & 22 & 6 \\
\hline
\end{tabular}

TABLE 4. Parents' answers in T0, $\mathrm{n}=30$ children, $\mathrm{p}<0,01, ?=0,05$.

\begin{tabular}{c|cccc}
\hline Perguntas & Incapaz & Intermedi/fio & Capaz \\
\hline 1 & 22 & 7 & 1 \\
2 & 21 & 9 & 0 \\
3 & 21 & 8 & 1 \\
4 & 25 & 4 & 1 \\
5 & 29 & 1 & 0 \\
\hline
\end{tabular}

(annex 2) responding the same questionnaire, applied in three different moments, pre-intervention (T0), after three months period of intervention (T1) and after 6 months period after intervention (T2). Teachers evaluated: children's interest in learning; attention/concentration in classroom; word reading; text reading, simple text interpretation, word dictation and copy. Parents' evaluation comprised: children's independence during homework, spontaneous reading of adds and labels, self-steam to learn; academic development and parent's confidence about their children.

Teachers and parents evaluation, respecting children's educational level and parent's considerations, was considered to data analysis, instead formal professional's evaluations. It is assumed that this method improves relations between the professionals, parents and school members, since all participates feel co-responsible during the learning process and positively collaborated to rehabilitation success.

\section{Results}

The questionnaires answered by the parents (5 questions) and by the teachers (7 questions), contained multiple choice answers with 5 alternatives each, with a growing degree of benefit. The incapable degree (without capacity to perform what was asked) was considered when the answers were in the first and second alternatives. Intermediate degree (with medium capacity to perform what was asked) was considered when the answers were in the two second alternatives. And capable degree (capable of performing what was asked), when the answers were in the last alternative.

The questionnaire results were described in tables from 1 to 6 and illustrated in graphs from 1 to 6 . They were not analysed separately by group in this study, but as a whole, once the purposes of the study did not distinguish the improvement of the Boquinhas Método (little mouth method) according to pathologies or different learning degrees.

The statistical analysis of the results used the non-parametric test of Smirnorf-Kolmogorov for a sample, and each question was analysed individually, compared in $\mathrm{T} 0, \mathrm{~T} 1$ and $\mathrm{T} 2$ for the 30 participants. The analysis of all questions obtained $\mathrm{p}<0,01$, with $?=0,05$ and $\mathrm{n}=30$. 
It is observed that in $\mathrm{T} 0$, that is, in the beginning of the treatment, the parents and the teachers judged the children as incapable, becoming capable in T2, that is, after 6 months of intervention. In T1, after 3 months of intervention some children had already gotten the capable concept, although there were some incapable answers, reflecting that in this interval the child is still in a transition phase, that is intermediate for the acquisition of the proposed content, only elaborating learning hypothesis.

\section{Discussion}

The speech-language science has the function of rehabilitate and prevent reading and writing disorders and difficulties, as described in its ethics code (Law 6965/81, version 2004), using methodologies and techniques that promote controllable results and possible to be evaluated considering the social dimensions of each subject. And, using this intervention consciously and efficiently, as well as helping the teachers' capacitating for this ability to be promoted, collaborate for our children's education where language has its role as support for learning.

The intervention described here by the Boquinhas method is not just a mechanical technique that dissociates the possibility of understanding and reflecting about writing as a language and its meanings from the child, nor it describes an homogeneous and fragmented action of language, as stress Massi and Berberian (2005); contrarily, it enables the child to face linguistic challenges just as well as the other students; once having actually learned to read it is possible to use the reading and writing safely and efficiently in a reflexive and contexted way. It is believed, as stresses Flôres (1994), which the metalinguistic abilities present individual variations attributed to different and particular metalinguistic experiences of the child, as well as to endogenous differences.

The proposal used as rehabilitation in this article agrees with Souza's (2005) findings, who defends the real necessity to encourage programs that implement the stimulation of the phonological and phonemic awareness abilities in the pre-school as a preponderant factor in the reading and writing learning, skills that are not spontaneously acquired by most of the children. For some children, the phonological information processing occurs
TABLE 5. Parents' answers in $\mathrm{T} 1, \mathrm{n}=30$ children, $\mathrm{p}<0,01, ?=0,05$.

\begin{tabular}{c|c|c|c}
\hline Perguntas & Incapaz & Intermedifrio & Capaz \\
\hline 1 & 11 & 18 & 1 \\
2 & 10 & 18 & 2 \\
3 & 10 & 18 & 2 \\
4 & 13 & 16 & 1 \\
5 & 13 & 16 & 1 \\
\hline
\end{tabular}

TABLE 6. Parents' answers in T2, $\mathrm{n}=30$ children, $\mathrm{p}<0,01, ?=0,05$.

\begin{tabular}{c|c|c|c}
\hline Perguntas & Incapaz & Intermedifrio & Capaz \\
\hline 1 & 0 & 20 & 10 \\
2 & 1 & 20 & 9 \\
3 & 1 & 18 & 11 \\
4 & 0 & 22 & 8 \\
5 & 1 & 23 & 6 \\
\hline
\end{tabular}

GRAPH 1. Teachers' questionnaire - incapable answer.

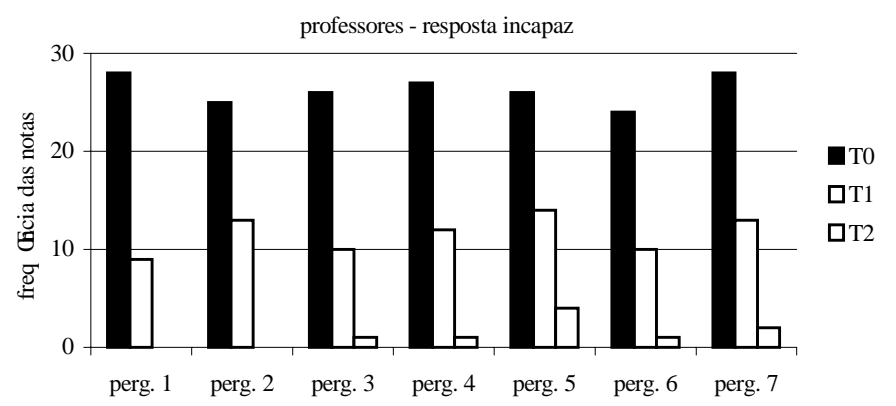

GRAPH 2. Teachers' questionnaire - intermediate answer.

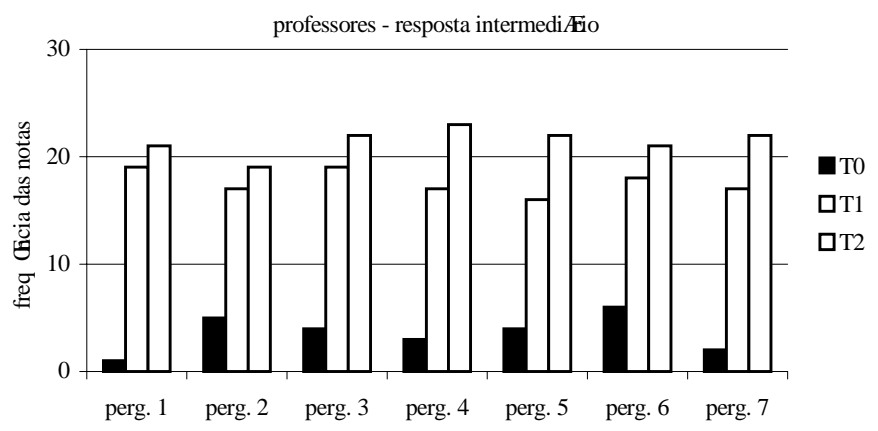


GRAPH 3. Teachers' questionnaire - capable answer.

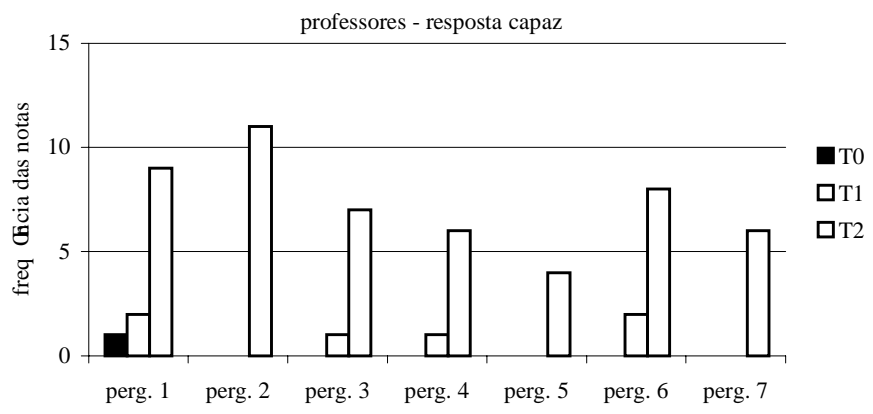

GRÁFICO 4. Questionário dos pais - resposta incapaz.

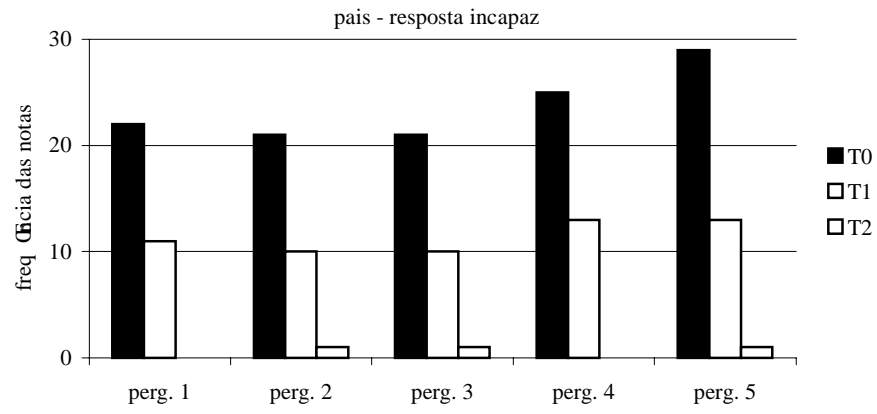

GRAPH 5. Parents' questionnaire - intermediate answer.

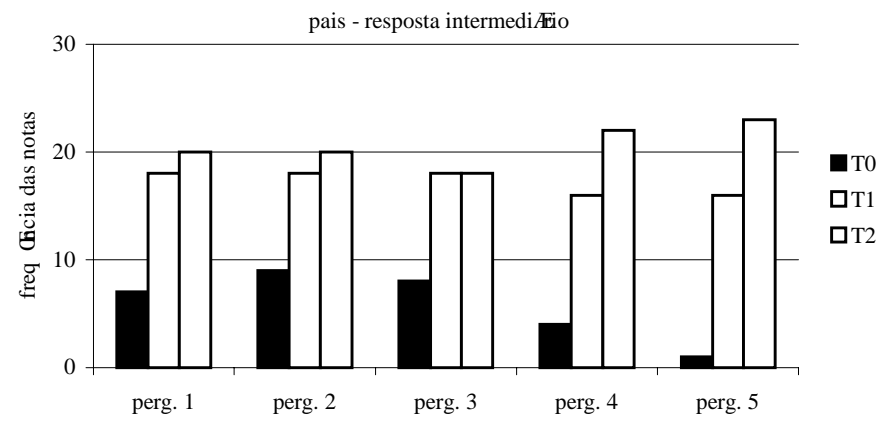

GRAPH 6. Parents' questionnaire - capable answer.

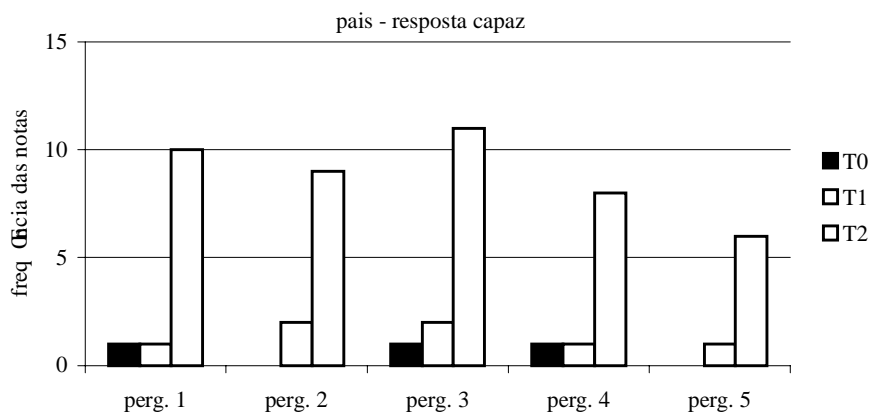

Alfabetização e reabilitação dos distúrbios de leitura/escrita por metodologia fono-vísuo-articulatória differently than expected (Vieira et al., 2004), presenting a phonological deviance characterised by disorganisation, non-adaptation or abnormality in the child's sound system in relation to the standard system of his linguistic community, without any organic component (Grunwell, 1990). This deviance is a dissociation of the expected, and not a disorder or a disturbance.

There is a correlation between the alphabetisation and the phonological awareness and these abilities develop in parallel (Morales et al., 2002). This proposal agrees with Capovilla and Capovilla (2002) who stress the importance of the alphabetisation learning from phonic units, since in the Portuguese language the most salient unit is the phoneme, and disagrees from the educational orientation offered by the pedagogical proposal of the Education Ministry - PCN - Portuguese language, which recommends the use of the alphabetisation global method.

Massi and Berberian (2005) report that the basic linguistic unit for the mastery of the reading and writing process is the discourse in its social and textual materiality, and not the syllable, word or sentence. It is believed that this should be applied to the mastery of reading and writing, which means the conscious use that is made of it, but maybe it does not apply to its acquisition, that is, to the alphabetisation, that is defended by the phonemic/ articulatory work that the Method proposes.

From the children's failure, it has been emerging a necessity of thinking a new pedagogical proposal worried with the cognition, with a greater emphasis in the last few years. However, the comprehension of its fundaments and, above all, of the pedagogical consequences of its implications is yet very poor among the educators. The natural outcome of this lack of knowledge are serious theoretical interpretation and practical application mistakes (Rosa, 1996). Thus, very often we see references to the Piaget method, to the Emília Ferreiro method, to constructivist method that, in essence, are inappropriate interpretations regarding how to teach instead of how to learn.

Methods are teaching steps and cannot be confused with learning processes (Rosa, 1996). By definition, the methods (meta = to and odos= way) propose ways to get to a certain end, that is what 
is intended with the Boquinha Method, that is, to use the conjunction of phoneme/grapheme/ articuleme in order to obtain the alphabetisation. Obtaining the mastery of reading and writing and becoming a reader is part of broader process that must be developed not only by the school but also by the whole society, including the family.

The direct work with the phonemes, in an explicit phonological awareness approach (Roazzi and Dowker, 1989) offers as a result a safer reading acquisition, improving its result and efficiency. The phonological analysis guides children regarding the speech sound system, favouring the code's rupture and facilitating the awareness (metacognition) by the child of the constructive elements of written language and of its functioning (Dominguez, 1994), enabling him to manipulate the oral language and to reflect upon it (AndrezzaBaletrin and Cielo, 2003). These facts are corroborated by investigation (Cielo, 2002) and favour the best linguistic performance, constituting the base for the child to automatize reading, which is an indispensable competence for understanding the meaning.

Cielo (2002); Flôres (1995); Capellini and Ciasca (2000) affirm that the linguistic awareness does not emerge abruptly in the child's brain, it develops in a continuum of successive ascending stages, not necessarily linear. It is the result of the biological development and maturation in constant exchanges with the context, favoured by the complex linguistic tasks to which it is submitted, including the reading learning.

We don't believe there is an infallible alphabetisation method where there are no breakdowns, nor a totally contra-indicated methodology. The partnership proposed here, of a parallel and integrated work between speech pathologist and pedagogue based on Boquinhas methodology, has been a theory reference for the alphabetisation, as well as for the correction of specific letters changes to be obtained in a short period of time, with consistency and safety. It is believe to maintain and keep the schooling of cases with reading and writing disorders.

\section{Conclusion}

This study allowed to conclude that in 6 months of intervention, all children significantly improved in all evaluated questions, either by their teachers as by their parents, showing that the reading and writing acquisition and rehabilitation have statistically significant results through the use of the Boquinhas method

Several professionals from public and private schools in order to habilitate and rehabilitate children in the alphabetisation phase have used this intervention; it can be applied in ordinary classrooms with all children. Recent studies developed by the authors, unpublished until this moment, have suggested that normal children get alphabetised in 3 to 4 months with the Boquinhas proposal, simply by being stimulated in their classrooms by the regular teacher, without any additional intervention. However, the reading and writing disorders described in this study need around 6 months of intervention to reach significant progresses, evaluated by their parents and teachers and being treated by a speech pathologist and a pedagogue in partnership.

Observation: the product "Carimbo das Boquinhas Pró-Fono" is a visual-pictographic method (MVP) distributed by Pró-Fono Specialised Products for Speech Pathologists since 1993 and contains drawings representing the phonoarticulatory organs (Tedesco and Masgall, 1993). This product does not have any relation with the Boquinhas Method presented here.

\section{Annex 1}

Teachers' questionnaier

1. Interest in learning:

0 . Refuses to learn.

1. Tries to learn but do not correspond what is demanded.

2. Participates the activity when is requested, but fail under pressure

3. Participates the activity when is requested, and correspond to.

4. Shows interest to what is offered and participates the activity adding examples.

2. Attention paid/concentration in classroom:

0 . Does not concentrate all the time and does not do the tasks.

\footnotetext{
1. Easily unfocus and only starts the task under pressure

2. Does the task when it is demanded, but makes mistakes.

3. Does the task when it is demanded, and succeeds.

4. Spontaneously pays attention to the tasks, and does it completely.

3. Word reading:

0 . Does not read.

1. Tries to read, but makes mistakes, which jeopardises text comprehension.

2. Reads a word making mistakes, but comprehend text meaning.
} 
3. Correctly reads words, but with syllabic segmentation, losing speech rate.

4. Correctly reads words, as fast as his/her peers do.

4. Simple text reading:

0 . Does not read.

1. Tries to read, but makes mistakes, which jeopardises text comprehension.

2. Reads words making mistakes, but comprehends text meaning.

3. Correctly reads words, but with syllabic segmentation, losing speech rate.

4. Correctly reads words, as fast as his/her peers do.

5. Simple text interpretation:

0 . Does not answer the text questions or just copies parts of the text.

1. Random answer text questions without understand it.

2. Answers text questions using poor structured sentences jeopardises the meaning

3. Answers the text question making mistakes, but correctly.

4. Correctly and clearly answer the text with no mistakes.

\section{Annex 2.}

Parent's questionnaire.

\section{Homework task independence:}

0 . Refuses to do it.

1. Does it with parent's presence and guidance.

2. Does it with parent's reading explanation.

3. Does it by him/herself, but with parent's homework correction.

4. Does it by him/herself.

2. Label, add, magazine and book spontaneous reading:

0 . Does not pay attention in written material.

1. Tries to read whenever it is demanded but does not comprehend its meaning.

2. Tries to read whenever it is demanded, with mistakes, but comprehend its meaning.

3. Correctly reads but only it demanded.

4. Spontaneously and correctly reads and makes some comments.

\section{Self-steam for learning:}

0 . Refuses to learn fells incapable.

1. Tries to learn but gives it up with the first mistakes

2. Asks for help, but feel bad about the mistakes.

3. Shows his/hers school activities, but making keeping on basic.

4. Accepts challenges, accepting his/her mistakes and positively correcting them.

\section{Referências Bibliográficas}

ALBANO, E. C. O gesto e suas bordas: esboço de fonologia articulatória do português brasileiro. Campinas: Mercado das Letras, 2001.

ANDREAZZA-BALESTRINI, C.; CIELO, C. A. O professor pré-escolar e sua prática em consciência fonológica. $R$. Soc. Bras. Fonoaudiol., São Paulo, v. 8, n. 1, p. 27 - 34, jun. 2003.

BROWMAN, C.; GOLDSTEIN, L. Towards an articulatory phonology. Phonol. Yearbook, v. 3, p. 219-252, 1986.

\section{Words Dictation:}

0 . Fails most words.

1. Fails about half of the words.

2. Misspells some words that jeopardise comprehension.

3. Misspells some words that do not jeopardise comprehension.

4. Correctly spell the words.

7. Board Copy:

0. Refuses to copy.

1. Copies by making mistakes, such as misfollow the line, omission, agglutination, which jeopardise comprehension. 2. Copies, making mistakes, such as misfollowing the line, omission, agglutination, which do not jeopardise comprehension.

3. Correctly copies, but slower than his/her peers

4. Correctly copies, but slower than classroom, as fast as his/her peers.
4. School performance according to parents:

0 . Does not follow the class, needs specific treatment.

1. Tries to follow the class, but with friends and teacher's guidance.

2. Follows that class but needs additional assistance.

3. Follows that class but needs additional assistance during term tests.

4. Has a grade as good as or better than his/her peers do. 5. Parent's credibility to his/her son/daughter learning potential:

0 . Will fail.

1. Will learn only with parental and professional guidance. 2. Makes effort to learning but needs assistance during term test.

3. Tends to pass but giving up under pressure.

4. Spontaneously uses his/her potential to learn and succeed expectations.
CAPELLINI, S. A.; CIASCA, S. M. Avaliação da consciência fonológica em crianças com distúrbio específico de leitura e escrita e distúrbio de aprendizagem. Temas Desenvol., v. 8, n. 48, p. 17-23, 2000.

CAPOVIlla, A. G. S.; CAPOVIlla, F. C. C. Alfabetização: método fônico. São Paulo: Memnon, 2002.

CARVAlHO, I. A. M.; ALVAREZ, R. M. A. Aquisição da linguagem escrita: aspectos da consciência fonológica. Fono Atual, v. 1, n.11 p. 28-31, 2000. 
CAVAlCANTE, C. A.; MENDES, M. A. M. A avaliação da consciência fonológica em crianças de primeira série alfabetizadas com metodologias diferentes. R. Cefac, v. 5, n. 3, p. 205-208, 2003.

CIASCA, S. M.; ROSSINI, S. D. R. Distúrbio de aprendizagem: mudança ou não? Correlação de dados de uma década de atendimento. Temas Desenvol., v. 8, n. 48, p. 11-16, 2000.

CIELO, C. A. A flexibilidade do paradigma conexionista. Letras Hoje, Porto Alegre, v. 33, n. 2, p. 43-49, 1998.

CIELO, C. A. Habilidades em consciência fonológica em crianças de 4 a 8 anos de idade. Pró-Fono R. Atual. Cient., Barueri, v. 14, n. 3, p. 301-312, set.-dez. 2002.

CIELO, C. A. Avaliação de habilidades em consciência fonológica. J. Bras. Fonoaudiol., v. 4, n. 16, p. 163-174, 2003.

COLLARES, C. C. L.; MOYSÉS, M. A. A. Diagnóstico da medicalização do processo de ensino: aprendizagem na $1^{\mathrm{a}}$ série do $1^{\circ}$ grau no Município de Campinas. Em Aberto, Brasília, v. 11, n. 53, p. 23-28, jan.-mar. 1992.

DOMÍNGUEZ, D. A. B. Importância de las habilidades de análisis fonológico en el aprendizage de la escritura. Estudios Psicol., v. 51, p. 59-70, 1994.

FERNÁNDEZ, A. Os idiomas do aprendente. Porto Alegre: Artes Médicas, 2001

FLÔRES, O. C. Da sensibilidade metadiscursiva à consciência metalingüística: o processo interativo como espaço de construção de sujeitos e de linguagem. Cad. Est. Ling., v. 26, p. 181-196, 1994.

FLÔRES, O. C. Consciência metapragmática. Letras Hoje, v. 30 , n. 2, p. 121-137, 1995.

FRAGA, M. L. O dilema da leitura e da escrita: com a palavra os professores. Fono Atual, v. 4, n. 15, p. 47-51, 2001.

FRANCHI, C. Linguagem: atividade constitutiva. Cad. Est. Ling., v. 22, n. 1, p. 9-39, 1992

GRUNWELL, P. Os desvios fonológicos evolutivos numa perspectiva lingüística. In: YAVAS, M. S. (Org.). Desvios fonológicos em crianças: teoria, pesquisa e tratamento. Porto Alegre: Mercado Aberto, 1990.

HULME, C.; HATCHER, P. J.; NATION, K.; BROWN, A.; ADAMS, J.; STUART, G. Phoneme awareness is a better pedictor of early reading skill than onset-rime awareness. J. Exp. Child. Psychol., v. 82, n. 1, p. 2-28, 2002.

JARDINI, R. S. R.; VERGARA, F. A. Alfabetização de crianças com distúrbios de aprendizagem, por métodos multissensoriais, com ênfase fono-vísuo-articulatória: relato de uma experiência. Pró-Fono R. Atual. Cient., Carapicuíba, v. 9, n. 1, p. 31-34, 1997.

JARDINI, R. S. R. Método das Boquinhas: alfabetização e reabilitação dos distúrbios da leitura e escrita. São Paulo: Casa do Psicólogo, 2003a. (Livro 1, fundamentação teórica).

JARDINI, R. S. R. Método das Boquinhas: alfabetização e reabilitação dos distúrbios da leitura e escrita. São Paulo: Casa do Psicólogo, 2003b. (Livro 2, caderno de exercícios).
JARDINI, R. S. R. Fonoaudiologia aliada à Psicopedagogia: um estudo de caso de dislexia. 2004a. 132f. Monografia (Especialização em Psicopedagogia) Centro Universitário Central Paulista, São Carlos, 2004a.

JARDINI, R. S. R. Método das Boquinhas: passo a passo da intervenção nas dificuldades e distúrbios da leitura e escrita. São Paulo: Casa do Psicólogo, 2004b.

LAZAROTTO, C.; CIELO, C. A. A consciência fonológica e sua relação com a alfabetização. R. Soc. Bras. Fonoaudiol., v. 7, n. 2, p. 15-24, 2002

MASSI, G. A.; BERBERIAN, A. P. A clínica fonoaudiológica voltada aos chamados distúrbios de leiturae escrita: uma abordagem constitutiva da linguagem. R. Soc. Bras. Fonoaudiol., São Paulo, v. 10, n. 1, p. 43-52, 2005.

MORALES, M. V.; MOTA, H. B.; KESKE-SOARES, M. Habilidades de consciência fonológica em crianças com desvio fonológico. J. Bras. Fonoaudiol., Curitiba, v. 3, n. 10, p. 72-75, 2002.

ROAZZI, A.; DOWKER, A. Consciência fonológica, rima e aprendizagem da leitura. Psic. Teor. Pesq., v. 5, n. 1, p. $31-55,1989$.

ROSA, S. S. Construtivismo e mudança. 4. ed. São Paulo: Cortez, 1996, v. 29.

ROTH, F. P.; BADEN, B. Investing in emergent literacy intervention: a key role for speech-language patolhogists. Sem. Speech Lang., v. 22, n. 3, p. 163-173, 2001.

SANTOS, M. T. M.; NAVAS, A. L. G. P. (Org.). Distúrbios de leitura e escrita. Barueri: Manole, 2002.

SOUZA, L. B. R. Cosnciência fonológica em um grupo de escolares da $1^{\text {a }}$ série de $1^{\circ}$ grau em Natal-RN. R. Soc. Bras. Fonoaudiol., São Paulo, v. 10, n. 1, p. 12-7, jan.-mar. 2005.

STACKHOUSE, J.; WELLS, B.; PASCOE, M.; REES, R. From phonological therapy to phonological awareness. Sem. Speech Lang., v. 23, n. 1, p. 27-42, 2002.

TANNÚS, C. G. B.; FELIPPE, A. C. N. Idade para alfabetização: opinião do professor e relação com o desempenho escolar. Pró-Fono R. Atual. Cient., Barueri (SP), v. 14, n. 3, p. 393-400, set.-dez. 2002.

TEDESCO, M. R. M.; MARGALL, S. A. C. Carimbo das Boquinhas. Produto desenvolvido e distribuído pela PróFono Produtos Especializados para Fonoaudiologia Ltda., Barueri, 1993.

VIEIRA, M. G.; MOTA, H. B.; KESKE-SOARES, M. Relação entre idade, grau de severidade do desvio fonológico e consciência fonológica. R. Soc. Bras. Fonoaudiol., v. 9, n. 3, p. 144-150, 2004.

YAVAS, F.; HAASE, G. V. Consciência fonêmica em crianças na fase de alfabetização. Letras Hoje, Porto Alegre, v. 23, n. 4, p. 31-55, 1988.

ZORZI, J. L. Consciência fonológica, fases da construção da escrita e seqüência de apropriação da ortografia do Português. In: MARCHESAN, I. Q.; ZORZI, J. L. Anuário Cefac de Fonoaudiologia. São Paulo: Revinter, 2000, p. 91-104. 